\title{
Human Resource Development Practices and Employees' Performance in a Ghanaian University: A Case of the University of Cape Coast
}

\author{
Blessed Ashmond1, Alexander Opoku-Danso1, Rebecca Asiedu Owusu² \\ ${ }^{1}$ School of Medical Sciences, College of Health and Allied Sciences, University of Cape Coast, Cape Coast, Ghana \\ ${ }^{2}$ School of Pharmacy and Pharmaceutical Sciences, College of Health and Allied Sciences, University of Cape Coast, Cape Coast, Ghana \\ Email: b.ashmond@uccsms.edu.gh, alexander.opoku-danso@ucc.edu.gh,rowusu@ucc.edu.gh
}

How to cite this paper: Ashmond, B., Opoku-Danso, A., \& Owusu, R. A. (2022). Human Resource Development Practices and Employees' Performance in a Ghanaian University: A Case of the University of Cape Coast. Journal of Human Resource and Sustainability Studies, 10, 77-97.

https://doi.org/10.4236/jhrss.2022.101006

Received: December 8, 2021

Accepted: March 5, 2022

Published: March 8, 2022

Copyright $\odot 2022$ by author(s) and Scientific Research Publishing Inc. This work is licensed under the Creative Commons Attribution International License (CC BY 4.0).

http://creativecommons.org/licenses/by/4.0/

\section{(c) (i) Open Access}

\begin{abstract}
The development of human resource is as important as managing it. This current study examines human resource development practices and employees' performance in the University of Cape Coast. Using both qualitative and quantitative research design, the study used a sample of 30 respondents from a homogenous staff population in the University of Cape Coast. Data were obtained from both primary and secondary sources. It was observed that formal classroom training is the most appropriate to offer staff with the adequate knowledge to perform one's job. It was also observed that training and development programmes initiated at the individual level is effective and most appropriate as compared to training and development organised for staff at the group level. The research article makes some recommendations for policy implication and this includes encouraging staff to embark on further studies to upgrade and add up to the knowledge required to perform their work. Also, the University of Cape Coast could consider having a pool of training programmes that staff could pick and choose for their further studies or their training programmes. Through the staff appraisal report forms filled and submitted by Heads of Department on behalf of their staff, the Directorate of Human Resource of the University of Cape Coast could tailor training and staff development programmes for individual staff or encourage and sponsor individual staff to undertake training and development programmes to equip them with the knowledge and skills that they lack as identified on the staff appraisal report forms.
\end{abstract}

\section{Keywords}

Employees' Performance, Human Resource Development (HRD), Training 
and Development (T \& D), Human Capital, Institution of Higher Learning, University of Cape Coast (UCC)

\section{Introduction}

\subsection{Background to the Study}

The development of human resource is as important as managing the human capital in any business establishment. Employees from time to time are given some form of training and staff development programmes to equip them to be abreast with constant change in technology and modern way of doing things. Human resource development strategies are set of systematic and planned activities designed by an organisation to provide its members with the necessary skills, knowledge, and capabilities to meet current and future job demands, in order to enable them provide better services and create good relations with customers and customer satisfaction (Adhikari, 2010). One aspect of human resource development that directly impacts on employees' performance and has attracted the attention of many social scientists and human resource practitioners is training and development.

Training and development practices positively impact organisational performance through employee satisfaction and customer loyalty and satisfied internal customers are conducive to increasing the productivity (Molina \& Ortega, 2003). Staff training and development programmes are a set of systematic and planned activities designed by an organisation to provide its members with the necessary skills to meet current and future job demands (Ratha, 2016). The university as a higher academic institution undertakes career development programmes to train employees to be abreast with modern way of doing things. Training improves the knowledge, skills and attitudes of employees for the short term, particular to specific job or task. Staff development prepares staff for future responsibilities, while increasing the capacity to perform at a current job. Staff training and development $(\mathrm{T} \& \mathrm{D})$ in the university as a higher educational institution solve a variety of manpower problems which militate against optimum productivity. These problems can emerge within any groups. Kayode (2001) notes that these problems differ in nature and yet all have a common denominator, the solution required individuals to their appreciative backgrounds specific identifiable items of additional knowledge skills or understanding. In the university administration, these problems, in the opinion of Asgarkhani (2004) include the needs to:

- Increase productivity

- Improve the quality of work and raise morale

- Develop new skills, knowledge, understanding and attitude

- Use correctly new tools, machines, processes, methods or modifications thereof

- Reduce waste, accidents, turnover, lateness, absenteeism, and other over- 
heads costs

- Implement new or changed policies or regulations

- Fight obsolescence in skills, technologies, methods, products, markets, capital management etc.

- Bring incumbents to that level of performance which meets 100 percent of the standard of performance for the job

- Develop replacements, prepare people for advancement, improve manpower deployment and ensure continuity of leadership

- Ensure the survival and growth of the organisation

Staff T \& D is very crucial in determining increase productivity and job satisfaction. Training new employees is estimated to cost approximately fifty percent of annual salary paid to workers (Boyens, 2007). University administration and management engage corporate management that is able to fulfil its objectives with the support of human resource development (HRD). The sustenance and progress of operation of higher education and other corporate sectors are inevitable without human resource dynamism (Pattanayak, 2003).

University management prefers the trained, professionals and specialised human resource (HR) for the achievement of planned objectives. Issues of ethics, success, competence of workers and ability of staff to perform up to required international standards are attained through quality HRD (Hellriegel et al., 2001). Institutions of higher learning employ and train staff to be able to cope with constant changes in technology. Bates (1999) observes that learning and staff development organised by corporate entities and individual level could translate to employees organisational performance. Employees' needs assessment is vital to determine which kind of $\mathrm{T} \& \mathrm{D}$ programmes required to do a particular job. Sutherland \& Jordaan (2004) contends that companies with high quality HR perform better and deliver higher and more consistent returns to ensure the growth of the companies.

The United Nations Development Programme (UNDP) (UNDP, 2005) posits that human development is about freedom. It is about building human capabilities, the range of things that people can do. Individual freedom and rights matter a great deal, but people are restricted in what they can do with that freedom if they are poor, ill discriminated against, threatened by violent conflict or denied a political voice. Provision of HRD programmes for staff in the university and academic institutions of higher learning is not enough to ensure optimum utilisation of skills and training offered to staff.

Sarbeng (2014) posits that, the performance of every organisation depends largely on the quality of their human resource. In addition, the nature of staff development policies and programmes in a higher academic institution impacts on its human resource skills and capabilities. In a research conducted in the University of Cape Coast on the assessment of staff training and development policies of University of Cape Coast, Sarbeng (2014) further argues that although the training policy in the University of Cape Coast is not perceived as fair; it has 
however, helped in the capacity building of the university and improved staff performance.

\subsection{Problem Statement}

A key goal of human resource development is to improve the performance in an organisation by maximising the efficiency and productivity of human resources. Human Resource Development plays a major role in creating and sustaining capabilities, thereby enhancing the competitiveness of the company. However, adopting a capability-driven approach to HRD is not the only concern of HRD managers, but also requires formulation of appropriate forms of management and business strategy (Mikko, 2000). London (1983) mentions learning and development orientation as one of many dimensions that compose the construct as career development. Learning and development orientation programmes take place at the group and individual initiated levels. Bates (1999) opines that learning at the individually level rather translates into their organisational performance.

Universities have established a Training and Development Sections to coordinate staff $\mathrm{T} \& \mathrm{D}$ activities and to implement programmes of the institutions. The T \& D policies of the universities aim at providing advice, opportunities, facilities and sponsorship (full or partial) to enable employees to train in the critical areas of specialties and needs (UCC, 2011). However, provision of T \& D policies should complement the relevance of $\mathrm{T} \& \mathrm{D}$ programmes to the job performance and also, the ability of staff to transfer knowledge acquired through $\mathrm{T}$ $\& \mathrm{D}$ on to the job.

The University of Cape Coast has been able to develop a number of staff in and outside Ghana (DHR, 2012; Sarbeng, 2014). However, the strategies in assessing the effectiveness of $\mathrm{T} \& \mathrm{D}$ programmes to staff performance are direct and affect the outcome and implications of the $\mathrm{T} \& \mathrm{D}$ programmes. The focus of this current study is to examine human resource development practices and employees' performance in the University of Cape Coast.

\subsection{Objectives of the Study}

The general objective of the study is to assess human resource development practice and employees' performance of staff of Ghanaian universities. Specifically, the study will achieve the following objectives:

1) To investigate the policies and procedure adopted by the University of Cape Coast to train and develop staff.

2) To determine the relevance of the knowledge and skills obtained from training and development programmes unto the job.

3) To ascertain whether training and development at the individual or group level translates into enhancing job performance.

4) To verify whether staff training and development policies of UCC complement $\mathrm{T} \& \mathrm{D}$ programmes and translate into employee performance.

5) To investigate the strategies adopted by UCC to assess the effectiveness of T 
\& D programmes.

\subsection{Research Questions}

The study will find answers to the following research questions:

1) What policies and procedures inform training and development of staff in the University of Cape Coast?

2) How do staff of UCC transfer acquisition of knowledge and skills through training and development programmes on their job?

3) How do training and development at the individual and group levels translate into enhancing job performance?

4) What strategies does UCC adopt to assess the effectiveness of training and development programmes for its staff?

\subsection{Scope of the Study}

The assessment of HRD practice on employee performance falls within the scope of HRD specifically $\mathrm{T} \& \mathrm{D}$. This current research will take a case study approach to examine HRD practice in a Ghanaian university specifically UCC. University of Cape Coast has three categories of staff namely Junior Staff, Senior Staff and Senior Members. Each of these three categories of staff requires special training and development needs. The T \& D policy of UCC (if any) will therefore spell out the training and development needs of each of the categories of staff it engages. University of Cape Coast is a complex institution with different departments, directorates, sections and institutes which will then require a different and special arrangement for HRD practice, approach and engagement.

\subsection{Significance of the Study}

Human Resource Development has attracted the attention of many scholars and researchers in the field of development studies and social sciences. This is because HRD practices have direct effect on employees' performance. This current study contributes to existing scholarship by adding to literature on assessment of HRD practices on employees' performance. It also promotes scholarship by updating information on training and development among staff of UCC. The study is also significant in the sense that it will provide useful information for policy formulation through conclusions that will be drawn and recommendations made. Policy makers will be informed through the findings and recommendations from this study to improve where necessary areas of HRD that require attention and intervention. In the University of Cape Coast, this current study will provide useful information to the DHR and in particular, the T \& D Section to improve its $\mathrm{T}$ $\&$ D programmes that will enhance efficiency and effectiveness of staff to ensure increase in productivity. Through the findings, conclusions and recommendations made from this current study, the DHR of UCC will also be informed to review and update its $\mathrm{T} \& \mathrm{D}$ policies to meet current HR practices. 


\subsection{Theories of Human Resource Development}

\section{Institutional theory}

The study of institutions traverses the academic fields of economics, sociology, political science and organisational theory. The common denominator for institutionalism in various disciplines appears to be that of "institutions matter" (Kaufman, 2011). An underlying assumption in the study of institutions is that organisations are deeply embedded in the wider institutional context (DiMaggio \& Powell, 1983). Thus, "organisational practices are either a direct reflection of, or response to rules and structures built into their larger environment" (Paauwe \& Boselie, 2003: p. 59). This institutional environment is the source of legitimisation, rewards or incentives for, as well as constraints or sanctions on organisational activities (Meyer \& Rowan, 1977). The relevance of institutional theory to HRD was initially derived from this view (Rosenzweig \& Nohria, 1994).

The institutional approach used in organisational analysis is referred to as organisational institutionalism (Greenwood \& Hinnings, 1996). Organisational institutionalism deals with the overall questions: "what does the institutional perspective tell us about organisational behaviour?" Institutional theory is a useful lens to analyse organisational behaviour because it can respond to empirical mismatch, where, "what we observe in the world is inconsistent with the ways in which contemporary theories ask us to talk" (March \& Olsen, 1984: p. 747). The theory is credited with its emphasis on the contextual, historical and processual aspects in which organisational actions take place (Currie, 2009). Human Resource Development scholars started to recognise the applicability of institutional theory to HRD research in early 1990s. Wright and McMahan (1992) were first to note this. Following this, Oliver (1997) and Purcell (1999) incorporated elements of the institutional framework in relation to HRD in their research. On research and institutionalisation, Scott (1995) and Zucker (1987) focus on pressures emanating from the internal and external environments. Internally, institutionalisation arises out of formalised structures and processes, as well as informal or emergent group and organisation processes. Forces in the external environment include those related to the state. For instance, in the university as an educational institution, the external forces are: legislation and regulations, national culture, globalisation, information technology and human resource practices within the same institutional enterprise.

The university institution has little or no control over these forces. However, they can influence it to some extent. On the other hand, the internal forces in the university institution from this study are the union such as, University Teachers Association of Ghana, Ghana Association of University Administrators, Senior Staff Association, Tertiary Educational Workers Union and human and logistical factors within the university institution such as training and development policy. Regardless of the source of institutional pressures, two central assertions of this perspective are: a) institutionalised activities are resistant to change and b) organisations in institutionalised environments are pressured to become similar 
(Meyer \& Rowan, 1977; DiMaggio \& Powell, 1983). Thus, in this theoretical perspective, context is the major explanation for both resistances to change and adoption of new HRDP approaches in the university institution. The first assertion suggests that HRDP activities have deep historical roots in the university institution, so they cannot be understood completely without analysing the institution's past. From the second assertion, it follows that HRDP activities may be adopted by the university institution simply because other institutions have done so. Thus, "managerial fads and fashions" ebb and flow in part because a few legitimate institutions become fashion leaders that are imitated by other institutions that view imitation as a low-risk want to gain acceptance (Abrahamson, 1991).

Tolbert and Zucker (1983) showed for example that institutionalisation resulting from imitation partially the rate at which reforms in civil service selection procedures spread throughout the country at the turn of the century. DiMaggio and Powell (1983) further elaborate this later assertion with the concept of "institutional isomorphism" defined as: "a constraining process that forces one unit in a population (or organisational field) to resemble other units that exposed to the same set of environmental conditions" (Boxall et al., 2007: p. 174). In line with this, the study builds on the institutional theory by assessing the human resource management practices in institutions of higher learning. Human Resource Management (HRM) practices are adopted and practiced in the universities because other institutions do same. Furthermore, the university institutions are pressured by employees for better condition of service of which training and development of staff is very paramount. This highlights the need to adopt a practice that best satisfies the demand of employees and at the same time, enhances their job performance. This is in consistent with the institutional theory.

\section{Human capital theory}

Human capital theory provides a justification for a large public expenditure on education in developing and developed nations. This theory suggests that education or training raises the productivity of workers by imparting useful knowledge and skills, hence raising workers' future income by increasing their life time earnings. The concepts of human capital theory was first used by the classicalist economists like Alfred Marshal and Adam Smith (although developed by Becker, 1964) which stresses the significance of education and training as the key to participation in the new global economic order.

Labour Economics study is on workforce in quantitative terms, thus has the most accurate predictability than other social sciences. This theory posits that human capital is similar to physical means of production which includes factories and machines. In this case, a higher level in the provisions of these physical means of production would as well result in an increased in productivity because one's output depends partly on the rate of return on the human capital one owns. Thus, human capital is a means of production into which additional in- 
vestment yields additional outputs. In summary, this theory is of the view that the most valuable of all capital is that invested in human being. Human capital of an organisation or country is strictly tied to the education in that country. It therefore advocates for a continuous increase in the amount of investment in human capital through education. The investment in human capital creates in the labour force the skill-based indispensable for economic growth.

\subsection{Training and Development as Tool for Human Resource Development}

Training and development practices have shown to increase employee motivation and to have a tremendous impact on the performance of academic institutions of high learning (Jiang et al., 2012). Academic institutions of higher are also among the most frequently studied incentives in the field of human resource development (Boselie \& Van der Wiele, 2002). The motivational effect from the point of view of employees in universities is attributed to the continuous development in knowledge that they receive from training and development initiatives. Jiang et al. (2012) opine that these initiatives help employees to cope with job tasks and teach them to master future roles. The motivation effect in employees as a result of training and development initiatives can be seen as related to employee engagement, since engagement is seen as a motivational construct (Wollard \& Shuck, 2011).

Institutions of higher learning including universities are required to prioritise the need to engage resources for these human resource development practices in order to ensure increase employees' work engagement through training and development initiative (Bakker \& Demevouti, 2008). Schaufeli and Bakker (2003) observe that work engagement more likely to increase when the skills and talents of employee fit the job demands. A meta-study by Huselid (1995) supports this notion, as selective staffing techniques in some academic institutions of higher learning were shown to enhance motivation employees and institutional performance. Appropriate training can develop higher institutional leaders at all levels including the knowledge and skills required to gain competency in order to manage change in their institutions and in any environment (John, 2000). Hellriegel et al. (2001) state that training of employees in the universities and academic institutions of higher learning increases higher productivity through better job performance, more efficient use of human resources, goals and objectives more effectively met, reduced cost due to less labour turnover, reduced errors, reduced accidents and absenteeism, more capable, and mobile workforce and retention of the existing staff. Huselid (1995) further added that, effective training techniques can produce significant performance results especially in customer care service, product development and capability in obtaining new skill set. Training and development enhance employee skills, knowledge and ability to enhance task performance of individual and in the long run increases overall institutional productivity (Huselid, 1995).

Wood (1999) argues that HRD practices appear to be universal across higher 
institutions of learning and whether or not the effectiveness of HRD is contingent upon factors influencing performance, training is still a necessary condition for higher academic institutional growth. However, Asgarkhani (2004) argues that the success of training is contingent upon the effectiveness of performance, planning and measurement. Training and development are surrounded by three fundamental aspects namely: process classification, selection of proposed methods, and delivery. Staff training and development practice is one of the most important aspects of HRD that is needed to keep universities and institutions of higher learning ahead of their competitors (Koch \& Steers, 1978). In a similar development, a study conducted by Mcgrath (1982) shows that higher institutions of learning that engage a systematic training of their workforce are more likely to enjoy the rewards of more productive workforce.

Silla et al. (2009) posit that, there has been a growing recognition of training and development and learning, as a source of sustained competitive advantage as employers introduce more skills specific forms of training in some areas. That is, training should impact new knowledge and skills if the training is relevant, meet employee and institutional needs, efficiently and effectively designed and delivered (Silla et al., 2009). When the results of training are reflected in improvement in relevant knowledge and the acquisition of relevant skills, employee job performance should improve provided that the skills learned in training transfer to the job (Buck \& Watson, 2002). Improvement in performance such as productivity, quality, and service are the training outcomes provided that the job is strategically aligned to the institution's needs. At the individual level, if the desired needs of employee are fulfilled through the training programme provided the desired outcome by the institution will be reached.

Some studies in universities on HRD practices such as benefit and training are positively related to performance because the practices motivate employees and "lock" them to their jobs (Grote, 2002). Grote (2002) further observes that training is a valuable activity for enhancing skills and improving staff performance, and that training can address some of the factors contributing to staff performance, such as perceived support from the supervisor, the agency and the community.

\subsection{Skills and Capacity Building: Meeting the Training and Development Needs of University Staff}

Human beings constitute the human resource needs of any institution of higher learning of which universities are no exception. When the human capital is recruited in an institution, training starts the same day, workers bring in their knowledge, skills and experience related to the jobs they perform. Leaders of universities who invest in the employees to change and adapt their behaviour, skills and knowledge concerning the business would experience high positivity and employee performance (Fullan, 2007). Hughes (2006) defines capacity building as the factors that act as requisite for the emergence of a learning society for employees. Fullan (2007: p. 58) defines capacity building as "a collective aspect 
in terms of strategic steps adopted to enhance group efficiency showing higher improvements in performances, expansion of resources and motivation among working persons". The results of the studies done by these researchers explain capacity building as simple concept incorporating strategic actions taken to enhance human and technical resources in order to develop learning skills (Al-Roubaie, 2010; Hughes, 2006).

Joseph and Dai (2009) suggest that universities and higher academic institutions should provide capacity development programmes for employees to increase new and improved knowledge for the enhancement of institutional growth. They further suggest that in this dynamic knowledge economy, capacity development programmes play important role of retaining and enhancing employee performance among university staff. Al-Roubaie (2010) also suggests that impact of capacity building boosts up human capital, physical infrastructure and new dimensions for research and development as value addition to improve HRD capacity base of universities. Abdollahi and Naveh (2011) confirm that higher academic institutions who invest in the employees to change and adapt their behaviour, skills and knowledge concerning the institutional issues would experience positive results in employee performance. Higher academic institutions who adopt the attitude of ensuring and providing on-the-job training to employees to learn new things would have dedicated and trustworthy workforce (Benson, 2006). The training programmes and their modules are of no benefit if they don't compensate the institutions of higher learning in terms of more skilled, learned, disciplined and punctuality of workers. The employees should also take steps to engage in self-development training programmes to grow and develop their talent and improve knowledge, skills and attitude (Benson, 2006).

Training and development and job satisfaction among university staff

University staff, from time to time organise training and development programmes for its staff for them to be abreast with modern technology and modern way of doing things. Training and development programmes are expected to sharpen employees and equip them with the necessary skills to perform their job effectively. Adesola, Oyeniyi and Adeyemi (2013) examine the relation between staff training and job satisfaction of employees. Their regression results showed that staff training had positive significant relationship with job satisfaction. Costen and Salazar (2011) investigated the impact of training and development on employee job satisfaction, loyalty and intent to stay in the business establishment. The results indicated that employees who perceived they had the opportunity to develop new skills were more satisfied with their jobs, more loyal and more likely to stay with the organisation.

Balozi and Abdullah (2014) examine the effects of training and development and employee relationships on job satisfaction among public colleges. Their regression findings indicated that training and development were positively and significantly related to employee job satisfaction. However, Farahbod and Arzi 
(2014) examine job satisfaction in relations to training and development. They observe that, training and development do not have any significant impact on employee job satisfaction (EJS). Yeow et al. (2012) study the effects of training among staff inn higher learning institutions. Using a correlation analysis, they find that job satisfaction significantly relates to training. That is, employee performance appraisal, training and promotion predicted EJS. Therefore, employee performance appraisal and training and development as element of HRD are essential prerequisites for EJS of staff in a public university to their jobs.

\section{Methodology}

\subsection{Study Area}

The study was undertaken in the University of Cape Coast which is situated in the Cape Coast Metropolis in the Central region of the Republic of Ghana. The UCC started as University College of Cape Coast (UCCC). The idea to establish UCC conceived was by the first president of Ghana, Dr. Kwame Nkrumah and his top officials and associates. He explained to the people of Cape Coast at Victoria Park on November 5, 1960 the unique role that the college would play in national development (UCC, Silver Jubilee Brochure, as cited by Kwarteng, Boadi-Siaw, \& Dwarko, 2012).

The University of Cape Coast was established in October, 1962 as a result of international commission appointed by the Ghana government in December, 1960. The UCCC was formally inaugurated on December 15, 1962, and placed in special relationship with the University of Ghana. Beginning in a few buildings taken over from a Teacher Training College located at the Southern section of the University of Cape Coast. The Government of Ghana, in 1964 assigned to each of the country's three public universities specific fields of operation, and in line with the emphasis on science education, the UCCC was renamed "The University College of Science Education" with special responsibility of training graduate teachers in Arts and Science for the secondary schools, teacher training colleges, polytechnics and technical institutions in Ghana. In 1966, following the change of government, the College reverted to its original name of the University College of Cape Coast (UCC, 2018).

In 1970, the College Council recommended to the government to upgrade the College to full university status with power to award its own degrees. Presently, the University has structured its degree programmes by de-coupling the study of professional education courses from the main degree courses. The University is organised into seventeen (17) Faculties/Schools and five (5) colleges. The establishment of the collegiate system in UCC came into force in $1^{\text {st }}$ August, 2014. The Colleges are: College of Humanities and Legal Studies; College of Education Studies, College of Agricultural and Natural Sciences, College of Health and Allied Sciences, and College of Distance Education. Apart from the main stream academic departments, UCC also has directorates, sections and centres for administrative purposes. 


\subsection{Research Design}

The study used mixed method research design which involves both qualitative and quantitative approaches to investigate HRD practices on employees' performance of staff in UCC. The term mixed method research design refers to an emergent methodology of research that advances the systematic integration or sustained programme of inquiry. The basic premise of this methodology is that, such integration permits a more complete synergistic utilisation of data than do separate quantitative and qualitative data collection and analysis (Creswell \& Plano Clark, 2011; Mertens, 2009). The qualitative research dimension of this current study will collect data from sectional heads and organisers of training and development programmes at the DHR of UCC. Content analysis of work and HRD policies of UCC will be examined to investigate the policies and, procedures adopted by UCC to train and develop its staff.

The quantitative dimension of this research adopted stratified sampling techniques to elicit data from respondents. UCC is stratified into colleges, departments and directorates. A sample was selected from each faculty to determine the appropriateness and ability of staff to transfer knowledge and skills obtained from $\mathrm{T} \& \mathrm{D}$ programmes unto the job, determine whether T \& D programmes at the individual level or group level translate into enhancing job performance.

\subsection{Study Population and Sampling Technique}

The study comprises all staff at UCC. There are three categories of staff at UCC namely Junior staff, Senior staff and Senior members which are made up of lecturers and registrars or senior administrative staff. A quota sample size of 30 respondents was drawn from the population. The administrative staff in the junior staff category are the clerks. The senior staff category is also made up of the teaching associates, and administrators. The senior members are made up of lecturers and senior administrative staff or registrars.

A quota sample size of 30 respondents was a reasonable size. This is because the same training and development programmes are organised for all the three categories of staff with specialty for each category. For example, Senior Administrative staff are put together and given the same in-service training and development programmes and this is the same in the case for Junior staff and Senior members. This means that no additional or different information would be obtained for adding more respondents to the sample size since the same information is likely to be obtained because the study population is homogenous, hence a proportionate sample size of 30 respondents is ideal for this current study. Administering questionnaire was used to obtain information on whether T \& D at the individual or group level translates into enhancing the workers performance.

\subsection{Data Sources, Collection and Instruments}

Data for this study were obtained mainly from primary and secondary sources. 
Information that were obtained through primary source with respect to this study include: the strategies adopted by UCC to assess the effectiveness of T \& D programmes to university staff, and appropriateness and ability of staff to transfer knowledge and skills obtained from T \& D programmes unto the job. The primary source also elicited information on whether $\mathrm{T} \& \mathrm{D}$ programmes help toward enhancing the workers' job performance. The data on the strategies adopted by UCC to assess the effectiveness of T \& D programmes were collected through interviewing and the instrument that was used is the interview guide. Again, administering of questionnaire was used to obtain information on whether $\mathrm{T} \&$ $\mathrm{D}$ at the individual or group level translates into enhancing the workers job performance. The source of the questionnaire was from all staff of the University (i.e. Junior staff, Senior staff and Senior members). A questionnaire which is a quantitative instrument was used because of the homogeneity nature of the population and also for the fact that the information required under this specific objective concern all the three categories of staff in the University of Cape Coast and were randomly sampled. Therefore numbers, percentages and frequencies which lend themselves to quantitative research design are required for this analysis and interpretation.

Secondary source of data in a form of content analysis was used to investigate the policies and procedures adopted by UCC to train and develop its staff. In addition to this, content analysis was done to verify whether $\mathrm{T} \& \mathrm{D}$ policies of UCC complement T \& D programmes and translate into employee performance. Documents that were consulted as secondary source for the purpose of content analysis include the Work, Employment and T \& D Policies of UCC.

\section{Data Analysis}

Researchers have analysed qualitative and quantitative data be done in diverse ways. The analytical frame chosen for a study depends on the theoretical and philosophical perspectives which inform it, the goal of the study, the questions addressed and the methodology used. The qualitative dimension of this study involves inductive analysis meaning that critical themes emerge out of the data (Sarantakos, 2005). In this regard, thematic analysis was done for information that were collected by means of interview guide. The findings of the interviewing were coded and transcribed. Presentation of findings and interpretations was done manually. The transcription involved listening to each tape repeatedly to become acclimatised with the conversations and carefully wrote them down the words of each interviewee.

The data that were obtained through survey were first coded and analysed with the help of the Statistical Product and Service Solution (SPSS). The outputs of the results were analysed, categorised, summarised and interpreted on thematic basis such as ascertaining whether T \& D at the individual or group level translates into enhancing job performance and ensure productivity. 


\subsection{Ethical Consideration}

Research is a dynamic process which involves researchers and respondents, and which is based on mutual trust and cooperation, as well as on promises and well accepted conventions and expectations. It is important that the rights and freedom of the respondents are respected. Data that were obtained from the respondents through interviewing and survey were handled with confidentiality. This is meant to ensure that no other person than the researcher has access to the information apart from the purpose for which the data is obtained.

It is also to ensure that no respondent is identified with the kind of information they provide. That is, the respondents were assured with the ethics of anonymity. The consent of the respondents was obtained before approaching them to provide information for the research. This is to ensure that their privacy is not compromised or intruded.

\subsection{Investigating into the Policies and Procedures Adopted by the University of Cape Coast to train and Develop Staff}

Staff T \& D continues to change to meet the changing needs of UCC and her staff. The fundamental aim of T \& D of staff is to help UCC to achieve her purpose as specified in the key thrusts of its strategic plan document. Investing in the $\mathrm{T} \& \mathrm{D}$ enables the staff to perform better and empower them to make use of their skills. The major aim of staff T \& D in UCC is to promote a culture of development within the University, assist staff to develop their potential and enhance their capabilities as well as increase their efficiency and effectiveness to their own benefit and that of the University. At page 6 of UCC Staff T \& D Policy document (UCC, 2011), the main objectives of staff T \& D are to:

1) Equip staff with competencies to improve their own performance as well as the performance of the University.

2) Reduce the learning time for newly employed as well as staff transferred to other departments/units or promoted and, ensure that these staff become efficient and effective as quickly as possible.

3) Increase staff understanding of and commitment to the mission and vision of the University.

4) Minimise redundancy, waste and staff turnover in the University.

5) Enhance the implementation of new University policies and regulations.

6) Eliminate obsolescence in skills, technologies and methods of operation in the University.

7) Improve human resource development and ensure the survival and growth of the University.

\subsection{Verifying Whether Staff T \& D Policies of UCC Complement T \& D Programmes and Translate into Employee Performance}

The training of staff in UCC is coordinated by the T \& D Board. In determining training programmes for staff, systematic assessment of training needs is carried 
out. Employees and their immediate supervisors are consulted about any training identified as relevant to their situation. The main aim of staff $\mathrm{T} \& \mathrm{D}$ activities is to support the pursuit of the University's goals. Training and Development activities are regarded as a key element in an individual's mastery of and satisfaction in his/her principal duties.

The University continues to provide for selected employees to participate in development activities to prepare them for new roles in the University. To this end, the University continues to use both internal and external methods of training and staff development. In using external out-of-job training methods, the University identifies critical areas and advertise them. The Board then selects applicants based on institutional needs, their qualification, annual assessment results and availability of funds.

\subsection{Determining the Appropriateness and Ability of Staff to Transfer Knowledge and Skills Obtained from Training and Development Programmes onto the Job}

In all, thirty (30) respondents were sampled from UCC to determine the appropriateness and ability of staff to transfer knowledge and skills obtained from T \& D programmes onto the job. Table 1 below gives the demographic distribution

Table 1. Socio-demographic characteristics of the respondents.

\begin{tabular}{lcc}
\hline & Frequency & Percentage \\
\hline Gender & & \\
Male & 19 & $63.33 \%$ \\
Female & 11 & $36.66 \%$ \\
Age & & \\
20 - 29 & 5 & $16.67 \%$ \\
30 - 39 & 15 & $50 \%$ \\
40 - 49 & 7 & $23.33 \%$ \\
50 - 59 & 3 & $10 \%$ \\
Department & & \\
Academic & 10 & $33.33 \%$ \\
Administration & 20 & $66.67 \%$ \\
Staff category & & \\
Junior staff & 5 & $16.67 \%$ \\
Senior staff & 10 & $33.33 \%$ \\
Senior members & 15 & $50 \%$ \\
No. of years served in UCC by the respondents & & \\
1 - 5 & 4 & $13.33 \%$ \\
6 - 10 & 17 & $56.67 \%$ \\
11 - 15 & 7 & $23.33 \%$ \\
Above 15 years & 2 & $6.67 \%$ \\
\hline
\end{tabular}

$\mathrm{N}=30$. Source: Field Survey, 2021. 
of the respondents:

Twenty (20) respondents who represent 66.67 percent responded that they have received both formal classroom training and periodic on-the-job training from UCC while 10 respondents representing 33.33 percent also responded that in addition to formal classroom education training and periodic on-the-job training organised by $\mathrm{T} \& \mathrm{D}$ of the University, they also sponsor themselves for short training courses. In assessing the appropriateness of these three staff training and development programmes, 26 respondents representing 83.33 percent are of the opinion that, all the three $\mathrm{T} \& \mathrm{D}$ programmes namely formal classroom education, periodic on-the-job training programmes and short training courses initiated and sponsored by the staff are appropriate in offering adequate knowledge to perform their job. Four (4) respondents who represent 13.33 percent are of the opinion that only formal classroom education provides them with the adequate knowledge needed to perform their job.

\subsection{Investigation into the appropriateness of Training and Development Programmes in Offering Staff the Adequate Knowledge to Perform Their Job}

In a sample of 30 respondents, 22 of them who represent 73.3 percent were of the opinion that formal classroom training is the most appropriate in offering staff with the adequate knowledge to perform their job. Six respondents who represent 20 percent responded that periodic on-the-job training programmes organised by T \& D Section of UCC is the most appropriate in offering adequate knowledge to perform their job. Two respondents who constitute 6.67 percent responded that both formal classroom education, periodic on-the-job training and short training courses initiated and sponsored by the staff all offer the same level of knowledge needed to perform their job adequately.

\subsection{Staff Training and Development Programmes at the Group and Individual Initiated Levels and Assessment of Effectiveness of Training and Development Programmes for UCC Staff}

Of a quota sample size of 30 respondents, 22 of them who represent 73 percent were of the opinion that staff $\mathrm{T} \& \mathrm{D}$ at the individual level is more appropriate than T \& D organised for a group of people. Five other respondents who represent 16 percent also responded that staff $\mathrm{T} \& \mathrm{D}$ at both group and individual initiated levels are all appropriate and effective in offering the needed knowledge to perform on the job and that, it all depends on the seriousness that the individual attaches to the $\mathrm{T} \& \mathrm{D}$ programme. Two other respondents who represent 6 percent were of the opinion that staff $\mathrm{T} \& \mathrm{D}$ at the group level is more appropriate than the individual initiated one. Respondents who were indifferent between $\mathrm{T} \& \mathrm{D}$ at both the group and individual levels gave their reason that, proper learning takes place in groups and at the same time at the individual levels. 


\section{Conclusion}

Based on the findings of the study, the following conclusions are made:

1) The University of Cape Coast has documented policies and procedures on training and development of its staff. These policies and procedures are codified at page 6 of UCC staff T \& D Policy document (2011). It is also concluded that these policies and procedures are tailored toward enhancing staff human resource development. The staff T \& D Policy of UCC also complement T \& D programmes and translate into employee performance, because they are coordinated by the Training and Development Board of the University.

2) All the three types of T \& D programmes namely: formal classroom education, periodic on-the-job training programmes and short training courses initiated by the individual staff of the University are appropriate to offer adequate knowledge to perform their job. However, among these three, formal classroom education provides the most appropriate and adequate knowledge needed to perform their job.

3) Staff training and development programmes that are initiated by the individual employee is more appropriate and preferred to T \& D programmes that are organised for a group of staff like training seminars, symposia and public lectures.

4) It is also concluded that the University of Cape Coast has laid down strategies to assess the effectiveness of Training and Development programmes for staff. Some of these strategies include: administrative evaluation questionnaire to staff after in-service training, requesting staff to produce report for sponsoring staff for further studies, seminars and conferences and requesting for copies of thesis/dissertation for staff who go on further studies. Staff of the University of Cape Coast are also required to produce certificates for attending conferences and further studies when they apply for promotion to the next rank.

\section{Recommendations}

Based on the findings above, the following recommendations are made for policy implications:

1) The University of Cape Coast as part of her training and development policy could encourage staff to embark on further studies to upgrade and add up to the knowledge required to perform their work since formal classroom learning and training were identified to be the most effective and appropriate in offering the staff the needed knowledge to perform their work.

2) The University of Cape Coast could consider having a pool of training programmes that the staff could pick and choose for their further studies or their training programmes. This pool of programmes could be compiled from staff needs assessment as identified on staff appraisal report forms which are submitted on behalf of the staff by Heads of Department periodically.

3) The Directorate of Human Resource of the University of Cape Coast could periodically invite training needs on specific areas from staff. This recommenda- 
tion is meant to avoid parallel and omnibus training and development programmes that do not address the staff knowledge and training needs. When the staff come up with their own areas of $\mathrm{T} \& \mathrm{D}$ programmes, it bridges the knowledge gap and solves the problems of brain drain that arises from mismatch of training programmes and knowledge required to perform specific tasks.

4) Through the staff appraisal report forms filled and submitted by Heads of Department on behalf of their staff, the DHR of UCC could tailor training and staff development programmes for individual or encourage and sponsor individual staff to undertake $\mathrm{T} \& \mathrm{D}$ programmes to equip them with the knowledge and skills that they are deficient in them as identified on the staff appraisal report forms.

\section{Conflicts of Interest}

The authors declare no conflicts of interest regarding the publication of this paper.

\section{References}

Abdollahi, B., \& Naveh, E. A. (2011). Employees Empowerment. Virayesh Publication.

Abrahamson, E. (1991). Managerial Fads and Fashions: The Diffusion and Rejection of Innovations. The Academy of Management Review, 16, 586-612. https://doi.org/10.2307/258919

Adesola, M. A., Oyeniyi, K. O., \& Adeyemi, M. A. (2013). Empirical Study of the Relationship between Staff Training and Job Satisfaction among Nigerian Banks Employees. International Journal of Academic Research in Economics and Management Sciences, 2, 108-115. https://doi.org/10.6007/IJAREMS/v2-i6/446

Adhikari, D. R. (2010). Human Resource Development (HRD) for Performance Management: The Case of Nepalese Organizations. International Journal of Productivity and Performance Management, 59, 306-324.

https://doi.org/10.1108/17410401011038883

Al-Roubaie, A. (2010). Building Indigenous Knowledge Capacity for Development. World Journal of Science, Technology and Sustainable Development, 7, 113-129. https://doi.org/10.1108/20425945201000008

Asgarkhani, M. (2004). The Need for a Strategic Foundation for Digital Learning and Knowledge Management Solutions. Electronic Journal of e-Learning, 2, 31-42.

Bakker, A. B., \& Demerouti, E. (2008). Towards a Model of Work Engagement. Career Development International, 13, 209-223. https://doi.org/10.1108/13620430810870476

Balozi, M. A., \& Abdullah, O. (2014). The Effect of Training and Development and Employee Relations on Job Satisfaction: A Case Study of Tanzania Public Service College. Asian Journal of Research in Business Economics and Management, 4, 153-161.

Bates, R. A. (1999). Measuring Performance Improvement. Advances in Developing Human Resources, 1, 47-67. https://doi.org/10.1177/152342239900100104

Becker, G. S. (1964). Human Capital: A Theoretical and Empirical Analysis with Special Reference to Education. The University of Chicago Press.

Benson, G. S. (2006). Employee Development, Commitment and Intention to Turnover: A Test of 'Employability' Policies in Action. Human Resource Management Journal, 16, 173-192. https://doi.org/10.1111/j.1748-8583.2006.00011.x 
Boselie, P., \& Van der Wiele, T. (2002). Employee Perceptions of HRM \& TQM, and the Effects on Satisfaction and Intention to Leave. Managing Service Quality: An International Journal, 12, 165-172. https://doi.org/10.1108/09604520210429231

Boxall, P., Purcell, J. Wright, P. (2007). The Oxford Handbook of Human Resource Management. Oxford University Press.

Boyens, M. (2007). Organizational Socialization, Career Aspirations and Turnover Intentions among Design Engineers. Leadership \& Organization Development Journal, 26, 424-441. https://doi.org/10.1108/01437730510617645

Buck, J. M., \& Watson, J. L. (2002). Retaining Staff Employees: The Relationship between Human Resources Management Strategies and Organizational Commitment. Innovative Higher Education, 26, 175-193. https://doi.org/10.1023/A:1017916922194

Costen, W. M., \& Salazar, J. (2011). The Impact of Training and Development on Employee Job Satisfaction, loyalty, and Intent to Stay in the Lodging Industry. Journal of Human Resources in Hospitality \& Tourism, 10, 273-284. https://doi.org/10.1080/15332845.2011.555734

Creswell, J., \& Plano Clark, V. L. (2011). Designing and Conducting Mixed Methods Research (2nd ed.). Sage.

Currie, W. (2009). Contextualising the IT Artefact: Towards a Wider Research Agenda for IS Using Institutional Theory. Information Technology \& People, 22, 63-77. https://doi.org/10.1108/09593840910937508

DHR (2012). Directorate of Human Resource Report. University of Cape Coast Press.

Di Maggio, P. S., \& Powell W. W. (1983). The Iron Cage Revisited: Institutional Isomorphism and Collective Rationality in Organisational Fields. American Sociological Review, 48, 47-60. https://doi.org/10.2307/2095101

Farahbod, L., \& Arzi, S. (2014). Mediating Role of the Job Satisfaction in the Relationship between Human Resource Management Practices and Employee Performance. Interdisciplinary Journal of Contemporary Research in Business, 6, 91-109.

Fullan, M. (2007). The New Meaning of Educational Change (4th ed.). Teachers College Press.

Greenwood, R., \& Hinnings, C. R. (1996). Understanding Radical Organisational Change: Bringing Together Old and New Institutionalism. Academy of Management Review, 21, 1022-1055. https://doi.org/10.2307/259163

Grote, R. C. (2002). The Performance Appraisal Question and Answer Book: A Survival Guide for Managers. AMACOM Division of American Management Association.

Hellriegel, D., Slocum Jr., J. W., \& Woodman, R. W. (2001). Organizational Behavior (pp. 6-31). South-Western College Publishing.

Hughes, K. D. (2006). Exploring Motivation and Success among Canadian Women Entrepreneurs. Journal of Small Business \& Entrepreneurship, 19, 107-120. https://doi.org/10.1080/08276331.2006.10593362

Huselid, M. A. (1995). The Impact of Human Resource Management Practices on Turnover, Productivity, and Corporate Financial Performance. Academy of Management Journal, 38, 635-672. https://doi.org/10.5465/256741

Jiang, K., Lepak, D. P., Hu, J., \& Baer, J. C. (2012). How Does Human Resource Management Influence Organizational Outcomes? A Meta-Analytic Investigation of Mediating Mechanisms. Academy of Management Journal, 55, 1264-1294.

https://doi.org/10.5465/amj.2011.0088

John, V. (2000). Managing Behaviour in Classrooms. London. David Fulton.

Joseph, K. E., \& Dai, C. (2009). HRM Practices and Organizational Performance: An Em- 
pirical Analysis. International Journal of Business and Management, 4, 117. https://doi.org/10.5539/ijbm.v4n8p117

Kaufman, B. E. (2011). Comparative Employment Relations: Institutional and Neo-Institutional. Andrew Young School of Policy Studies Research Paper Series No. 10-3. https://doi.org/10.2139/ssrn.1565567

Kayode, T. (2001). The Role of Training in Change Management. Journal of Institute of Personnel Management of Nigeria, 10, 24-31.

Koch, J. L., \& Steers, R. M. (1978). Job Attachment, Satisfaction, and Turnover among Public Sector Employees. Journal of Vocational Behavior, 12, 119-128.

https://doi.org/10.1016/0001-8791(78)90013-1

Kwarteng, K. O., Boadi-Siaw, S. Y., \& Dwarko, D. A. (2012). A History of the University of Cape Coast. Cork University Press.

London, M. (1983). Toward a Theory of Career Motivation. Academy of Management Review, 8, 620-630. https://doi.org/10.5465/amr.1983.4284664

March, J. G., \& Olsen, J. P. (1984). The New Institutionalism: Organizational Factors in Political Life. The American Political Science Review, 78, 734-749. https://doi.org/10.2307/1961840

McGrath, J. (1982). Dilemmatics: The study of research choices and dilemmas. In J. M. Joseph, E. McGrath, \& R. A. Kulka (Eds.), Judgment Calls in Research (pp. 69-102). Saga Publications.

Mertens, D. M. (2009). Transformative Research and Evaluation. Guilford Publications.

Meyer, J. W., \& Rowan, B. (1977). Institutionalized Organizations: Formal Structure as Myth and Ceremony. American Journal of Sociology, 83, 340-363.

https://doi.org/10.1086/226550

Mikko, L. (2000). Developing People for Business Success: Capability-Driven HRD Practice (p. 152). MCB University Press Ltd.

Molina, J. A., \& Ortega, R. (2003). Effects of Employee Training on the Performance of North-American Firms. Applied Economics Letters. Tailor \& Francis.

Oliver, C. (1997). Sustainable Competitive Advantage: Combining Institutional and Resource-Based Views. Strategic Management Journal, 18, 697-713. https://doi.org/10.1002/(SICI)1097-0266(199710)18:9\%3C697::AID-SMJ909\%3E3.0.C O;2-C

Paauwe, J., \& Boselie, P. (2003). Challenging 'Strategic HRM' and the Relevance of the Institutional Setting. Human Resource Management Journal, 13, 56-70. https://doi.org/10.1111/j.1748-8583.2003.tb00098.x

Pattanayak, B. (2003). Gaining Competitive Advantage and Business Success through Strategic HRD: An Indian Experience. Human Resource Development International, 6, 405-411. https://doi.org/10.1080/13678860210140913

Purcell, J. (1999). Best Practice or Best Fit: Chimera or Cul-de-sac. Human Resource Management Journal, 9, 26-41. https://doi.org/10.1111/j.1748-8583.1999.tb00201.x

Ratha, D. (2016). Migration and Remittances Fact Book 2016 (3rd ed.). World Bank Group.

Rosenzweig, P. M., \& Nohria, N. (1994). Influences on Human Resources Management Practices in Multinational Corporations. Journal of International Business Studies, 25, 229-251. https://doi.org/10.1057/palgrave.jibs.8490199

Sarantakos, S. (2005). Social Research (2nd ed.). Palgrave Publishers Ltd.

Sarbeng, I. B. (2014). Assessment of Staff Training and Development Policies of Univer- 
sity of Cape Coast. European Journal of Business and Management, 6, 68-78.

Schaufeli, W. B., \& Bakker, A. B. (2003). Utrecht Work Engagement Scale: Preliminary Manual. Occupational Health Psychology Unit, Utrecht University. https://doi.org/10.1037/t76451-000

Scott, W. R. (1995). Institutions and Organisations. Sage Publications.

Silla, I., De Cuyper, N., Gracia, F. J., Peiró, J. M., \& De Witte, H. (2009). Job Insecurity and Well-Being: Moderation by employability. Journal of Happiness Studies, 10, Article No. 739. https://doi.org/10.1007/s10902-008-9119-0

Sutherland, M. M., \& Jordaan, W. (2004). Factors Affecting the Retention of Knowledge Workers. SA Journal of Human Resource Management, 2, 55-64.

https://doi.org/10.4102/sajhrm.v2i2.39

Tolbert, P. S., \& Zucker, L. G. (1983). Institutional Sources of Change in the Formal Structure of Organisations: The Diffusion of Civil Service Reform 1880-1935. Administrative Science Quarterly, 28, 22-39. https://doi.org/10.2307/2392383

UCC (University of Cape Coast) (2011). Training and Development Policy. University of Cape Coast.

UCC (University of Cape Coast) (2018). Annual Diary Publication. University of Cape Coast.

UNDP (United Nations Development Programme) (2005). The State of Human Development. Kevin Watkins-2005 (p. 18). Oxford University Press.

Wollard, K. K., \& Shuck, B. (2011). Antecedents to Employee Engagement a Structured Review of the Literature. Advances in Developing Human Resources, 13, 429-446. https://doi.org/10.1177/1523422311431220

Wood, S. (1999). Getting the Measure of the Transformed High-Performance Organization. British Journal of Industrial Relations, 37, 391-417. https://doi.org/10.1111/1467-8543.00134

Wright, P. M., \& McMaham, G. C. (1992). Theoretical Perspective for Strategic Human Resource Management. Journal of Management, 18, 295-320. https://doi.org/10.1177/014920639201800205

Yeow, J. A., Chow, M. M., Kavitha, R., \& Koe, W. L. (2012). The Effects of Training among Academic Staff in Private Higher Learning Institutions. Canadian Psychology, 39, 33-51.

Zucker, L. G. (1987). Institutional Theories of Organisation. Annual Review of Sociology, 13, 443-464. https://doi.org/10.1146/annurev.so.13.080187.002303 